REFLEKSI HUKUM

Jurnal Ilmu Hukum
p-ISSN 2541-4984 | e-ISSN 2541-5417

Volume 3 Nomor 2, April, Halaman 209-222

DOI: https:/ / doi.org/ 10.24246/jrh.2019.v3.i2.p209-222

Open access at: http://ejournal.uksw.edu/refleksihukum

Penerbit: Fakultas Hukum Universitas Kristen Satya Wacana

\title{
MORALITAS UNDANG-UNDANG: KAJIAN FILOSOFIS TERHADAP UNDANG-UNDANG NOMOR 17 TAHUN 2014 TENTANG MPR, DPR, DPD DAN DPRD (MD3)
}

\author{
Kuswanto \\ Fakultas Hukum Universitas Darul 'Ulum Jombang \\ Korespondensi: kuswanto.undar@gmail.com
}

\begin{abstract}
Abstrak
Artikel ini merupakan studi filsafat hukum dengan menggunakan pendekatan filosofis ketika melakukan analisis yuridis. Artikel ini mengkritisi proses pembentukan Undang-Undang No. 17 Tahun 2014 tentang Majelis Permusyawaran Rakyat, Dewan Perwakilan Rakyat, Dewan Perwakilan Daerah dan Dewan Perwakilan Rakyat Daerah dan hasilnya dengan mempertanyakan komitmen pembentuknya pada moralitas. Moralitas tersebut melarang terjadinya conflict of interest dalam menetapkan undang-undang. UU No. 17 Tahun 2014 menjadi objek kritisisme karena gagal dalam memenuhi tes moralitas untuk disebut sebagai hukum. Artikel ini selanjutnya berargumen bahwa setiap undang-undang harus dapat dibenarkan dari titik berdiri moralitas. Jika pembentuk undang-undang tidak mampu memenuhi tuntutan tersebut maka undang-undangnya akan diberi label sebagai undangundang yang buruk.
\end{abstract}

Kata Kunci: Moralitas; Undang-Undang; Hukum.

\begin{abstract}
This article represents a legal philosophy study which applies philosophical approach while undertaking juridical analysis over the legal drafting of Law No. 17 of 2014 on the People's Consultative Assembly, the People's Representative Council, and the Regional Representatives Council. This article discovers a problem regarding on the moral commitment of the legal drafters of the Law. Ideally, the moral commitment requires the legal drafters to be cautious about the possibility of conflict of interest while drafting the Law. Unfortunately, Law No. 17 of 2014 does not represent the moral commitment, meaning it has failed the morality test to be called as law. This article also argues that legislation shall be justified by morality. If the law maker is unable to meet the precondition, the legislation will be labeled as an unjust law.
\end{abstract}

Keywords: Morality; Legislation; Law. 


\section{PENDAHULUAN}

Undang-Undang Nomor 17 Tahun 2014 tentang Majelis Permusyawaratan Rakyat, Dewan Perwakilan Rakyat, Dewan Perwakilan Daerah dan Dewan Perwakilan Rakyat Daerah (UU MD3) adalah salah satu UU paling kontroversial yang pernah dihasilkan di Indonesia karena sangat kuat nuansa kepentingan politiknya. Salah satu sumber kontroversinya adalah pengaturan mekanisme penentuan Pimpinan Dewan Perwakilan Rakyat (DPR) yang meniadakan hak partai politik pemenang pemilu untuk secara otomatis mendapatkan posisi sebagai Ketua DPR. Oleh karena itu, merespons atau menanggapinya menjadi tujuan dari tulisan ini. Isu sentral dari tulisan ini dalam mengkritisi UU MD3 adalah: Apakah UU MD3 dapat dibenarkan secara filosofis dari titik berdiri moralitas?

Walaupun isu ini secara politik sudah tidak aktual lagi, namun secara substantif isu ini akan selalu relevan dalam diskusi kita tentang teori perundang-undangan atau legisprudence. Isu substantifnya di sini adalah pembentukan UU, termasuk perubahan UU, yang didasari oleh kepentingan sempit dan jangka pendek yang menggambarkan adanya legislative intent yang buruk dari pembentuk UU, sehingga UU yang dihasilkan juga buruk, dalam hal ini bertentangan dengan moralitas, walaupun secara kekuasaan, dalam hal ini kekuasaan membentuk UU, hal itu mungkin dilakukan. Meski secara politik UU MD3 sudah tidak relevan, tetapi UU ini dapat menjadi contoh yang baik untuk penerapan tolok ukur moralitas ke dalam proses dan hasil dari aktivitas pembentukan UU, dengan harapan supaya UU dapat "bermoral". Dewasa ini sudah semakin jarang ada UU yang dihasilkan dengan jalan menegasikan prinsip-prinsip moralitas dasar secara terang-terangan, dan UU MD3 ini adalah pengecualiannya. Masalahnya adalah, meskipun merupakan UU di bidang politik, pengaturan aktivitas politik tetap harus mengindahkan moralitas. UU MD3 sangat sulit dipertahankan dari titik berdiri moralitas. Tulisan ini akan menjustifikasi argumen tersebut dengan sistematika sebagai berikut.

Pertama, penulis akan menjelaskan bahwa hukum dan moralitas memiliki hubungan sangat erat sebagai konsep ontologis hukum yang hakiki. Kedua, penulis akan menjelaskan bahwa UU sebagai manifestasi hukum harus mencerminkan moralitas. UU yang gagal memenuhi tuntutan tersebut sangat sulit untuk dianggap memenuhi kualifikasi sebagai hukum. Ketiga, sebagai implikasinya, penulis akan menjelaskan argumen utama tulisan ini bahwa UU MD3 tidak memenuhi kualifikasi sebagai UU yang bermoral. UU MD3 lebih condong sebagai politik atau kekuasaan ketimbang sebagai hukum walaupun di mata pembentuk UU dimaknainya sebagai hukum. Terkait dengan itu penulis juga akan menanggapi, sebagai anotasi, pandangan Mahkamah Konstitusi (MK) yang bersikap bebas nilai ketika menguji konstitusionalitas UU MD3 seperti tertuang dalam Putusan MK No. 73/PUU-XII/2014. Hal ini menurut hemat penulis adalah isu sangat serius 
jika dikaitkan dengan komitmen MK sebagai pengawal konstitusi. Sikap bebas nilai tersebut dapat berimplikasi degradasi moral atas konstitusi itu sendiri. ${ }^{1}$

\section{PEMBAHASAN}

\section{Hukum dan Moralitas}

Isu spesifik sub-judul ini adalah konsep ontologis hukum, terutama konsepsi tentang hukum yang sebenarnya. Konsep ontologis hukum merupakan isu sangat serius karena konsepsi yang benar mengenai hukum dewasa ini sudah mengalami pergeseran sangat jauh, dan mendekati tahap kemapanan, dengan kekuasaan monopolistik dari negara sebagai produsennya yang menghasilkan konsep hukum positif, dan ajaran positivisme yuridis (legal positivism) sebagai sumber legitimasinya. Salah satu contoh, implikasi dari perkembangan tersebut, adalah pengutamaan hukum positif sebagai satu-satunya yang valid sebagai hukum serta pendirian bebas-nilai atau deskriptif mengenai hukum. Tentang ajaran positivisme Raymond Wacks menjelaskan: "emphasis on describing law by reference to formal rather than moral criteria. In their pursuit of a 'scientific' analysis of law and legal rules, it is their contention that the law as laid down (positum) should be kept separate - for the purpose of study and analysis - from the law as it ought morally to be."2

Konsepsi yang otentik mengenai hukum, bukan konsepsi positivis mengenai hukum, sudah kurang dipahami lagi. Padahal dengan pemahaman yang memadai tentang konsepsi tersebut maka hal itu akan mampu memperbaiki secara signifikan praktik hukum yang dikritik secara tajam oleh gerakan hukum progresif yang disponsori oleh sosiolog hukum terkemuka Indonesia, Satjipto Rahardjo. ${ }^{3}$ Kritik gerakan hukum progresif pada hakikatnya adalah kritik terhadap praktik hukum yang didominasi oleh ajaran positivisme yuridis yang sesungguhnya secara inheren salah dalam memahami konsepsi hukum yang hakiki, sehingga gambar hukum yang demikian besar diredusir "to formal rather than moral criteria" - meminjam pendapat Raymond Wacks di atas.

Meluruskan salah paham di atas, penulis berpendapat, perbedaan hakiki antara hukum dengan hukum positif (yaitu the law as laid down) perlu dipahami lebih dahulu. Pemahaman demikian sangat terbantu oleh pandangan Roscoe Pound dalam kuliah umum memperingati 100 tahun the School of Law, the University of Georgia, 1959. Dalam kuliah umum tersebut Pound menyatakan:

"In establishing an ordered society men have used two fundamental ideas, one

$1 \quad$ Tentang posisi normatif sebagai posisi yang seyogianya bagi MK lihat Titon Slamet Kurnia, Interpretasi Hak-Hak Asasi Manusia oleh Mahkamah Konstitusi Republik Indonesia: The Jimly Court 2003-2008 (Mandar Maju 2015) 74-129.

2 Raymond Wacks, Understanding Jurisprudence: An Introduction to Legal Theory (Oxford University Press 2012) 58.

3 Adriaan Bedner, 'Indonesian Legal Scholarship and Jurisprudence as an Obstacle for Transplanting Legal Institutions' (2013) 5 Hague Journal on the Rule of Law 253, 264. 
moral, an idea taken from ethics, and the other political, an idea taken from political science. From the one we develop the idea of reasoned adjusment of relations and ordering of conduct in accord with principles. From the other we develop the idea of sanctioned rules imposed and enforced by a sovereign political authority. The one gives us law. The other gives us rules of law or laws." 4

Pemikiran ini relatif jarang dibicarakan, padahal untuk menjelaskan konsep ontologis hukum yang sebenarnya, makna pernyataan tersebut sangat fundamental. Ketika menyajikan pendapatnya, Pound berhadapan dengan audiens yang pemahaman hukumnya sangat dipengaruhi ajaran positivisme yuridis. Oleh karena itu dalam mengemas pemikirannya secara filosofis Pound memilih jalur nonkonvensional, yaitu membicarakan sesuatu yang dalam bahasa Inggris sebagai bahasa ibunya, konsep tersebut sangat sukar untuk dideskripsikan. Di sini Pound mengajak audiensnya untuk memahami bahwa hukum dan UU (hukum positif) tidak sama. Dalam bahasa Latin, pernyataan di atas diwakili istilah "ius" (atau law) dan "lex" (atau laws); sementara bahasa Inggris tidak memiliki padanan yang presisi untuk dua konsep. 5

Seperti dijelaskan Pound, hukum (law atau ius) bersumber dari gagasan moral atau etis sebagai "the idea of reasoned adjusment of relations and ordering of conduct in accord with principles". Konsepsi ini berbeda dengan hukum positif (laws atau lex) yang bersumber dari kekuasaan, yaitu "the idea of sanctioned rules imposed and enforced by a sovereign political authority". Dengan pengertian lain, konsepsi hukum yang dominan saat ini adalah konsepsi yang etatis, menekankan pada peraturan-peraturan formal yang bersumber dari negara sebagai hukum yang eksklusif; dus, inilah inti ajaran positivisme yuridis.

Dalam situasi demikian, untuk menuju pada konsepsi hukum yang benar, perlu dilakukan rekonstruksi atas konsep ontologis hukum tersebut secara konseptual maupun secara historikal. Dalam konteks demikian penulis sependapat dengan Pound. Lebih lanjut, memperjelas pemikirannya mengenai perbedaan antara hukum dan hukum positif, Pound menyatakan:

"Law is a body of ideals, principles, and precepts for the adjusment of the relations of human beings and the ordering of their conduct in society. Law seeks to guide decision as laws seek to constrain action. Law is needed to achieve and maintain justice. Laws are needed to keep the peace - to maintain order. Law is experience developed by reason and corrected by further experience. Its immediate task is the administration of justice; the attainment of full and equal justice to all. The task of laws is one of policing, of maintaining the surface of order."6

Kata kunci dalam usaha untuk rekonstruksi atas konsep ontologis hukum tersebut adalah hukum merupakan " $a$ body of ideals, principles, and precepts for the adjusment of the relations of human beings and the ordering of their conduct in society."

Roscoe Pound, Law Finding Through Experience and Reason (University of Georgia Press 1960) 4.

Ibid., 3-4.

Ibid., 1-2. 
Dalam proses adjusment dan ordering tersebut, hukum mengandung tuntutan inheren sebagai ciri khasnya karena bersumber dari gagasan moral atau etis yaitu "to achieve and maintain justice." Hal itu berbeda dengan hukum positif yang berusaha "to constrain action" dan "maintaining the surface of order."

Sementara secara historikal, konsep hukum positif sebenarnya adalah konsep relatif baru dibandingkan dengan konsep hukum itu sendiri. John Salmond menyatakan: "Early law is conceived as jus (the principles of justice), rather than as lex (the will of the State). The function of the State in its earlier conception is to enforce the law, not make it."7 Dengan demikian dapat disimpulkan bahwa konsep hukum positif pada hakikatnya merupakan fenomena modernisasi hukum dengan perantaraan negara melalui proses formalisasi. Oleh karena itu, UU (hukum positif) bukan sesuatu yang secara filosofis taken for granted sebagai hukum.

Pada posisi tersebut pemikiran yang dikemukakan Pound sangat relevan. Sebagai sebuah tradisi berpikir filsafati, ajaran positivisme yuridis tidak tepat jika digolongkan sebagai salah satu aliran dalam filsafat hukum karena ajaran tersebut tidak mengandung unsur filsafati dengan usahanya menghindari isu sentral tentang kebenaran substansial dari hukum positif dengan posisi bebas nilai. 8 Itulah alasan yang menjelaskan mengapa Lon L. Fuller mengkritik keras ajaran positivisme yuridis H.L.A. Hart dengan menyatakan: "The respect we to human laws must be surely be something different from the respect we accord to the law of gravitation."9

Menariknya, posisi yang telah penulis gambarkan di atas ternyata tidak hanya sekadar abstraksi, tetapi juga mengandung nilai praktikal. MK Jerman (The Federal Constitutional Court) dalam kasus konstitusionalitas UU kewarganegaraan masa pemerintahan Nazi (BVerFGE 23 [1968]) menyatakan pendapat yudisial untuk putusannya:

"Law and justice are not left to the discretion of the lawmaker. The idea that a 'constitutional framer can arrange everything as he pleases would mean reverting to a mental posture of valuefree statutory positivism that has long since been obsolete in legal science and practice. Precisely the period of the National Socialist regime in Germany has taught that lawlessness [Unrecht] can issue even from the lawmaker.' Therefore, the Federal Constitutional Court has affirmed the possibility of revoking the legal validity of National Socialist 'legal' provisions when they conflict with fundamental principles of justice so evidently that the judge who elected to apply them or to acknowledge their legal consequences would be

$7 \quad$ Roger A. Shiner, A Treatise of Legal Philosophy and General Jurisprudence Vol. 3: Legal Institutions and the Sources of Law (Springer 2005) 8.

8 Terutama hal ini nampak secara spesifik dalam ajaran the Pure Theory of Law Hans Kelsen. Menjelaskan ajarannya Kelsen menyatakan: "It is called a 'pure' theory of law, because it only describes the law and attempts to eliminate from the object of this description everything that is not strictly law: Its aim is to free the science of law from alien elements. This is the methodological basis of the theory." Hans Kelsen, The Pure Theory of Law (University of California Press 1967) 1.

9 Lon L. Fuller, 'Positivism and Fidelity to Law - A Reply to Professor Hart' (1958) 71 Harvard Law Review 630,632 . 
administering lawlessness [Unrecht] rather than law."10

Pendapat tersebut secara dikotomis membedakan konsep hukum (keadilan) dengan UU, dan oleh karena itu hukum (keadilan) tidak boleh menjadi monopoli pembentuk UU. MK Jerman meyakini bahwa, sebagai implikasinya, pembentuk UU dapat menghasilkan UU yang tidak sesuai dengan hukum (lawlessness/unrecht). Pendapat MK Jerman secara genealogis mengadopsi pemikiran pasca perang dunia kedua yang dikemukakan Gustav Radbruch sebagai revisi atas pemikiran sebelumnya. Radbruch menggarisbawahi bahwa hal penting dari hukum adalah nilai, bukan kekuasaan. ${ }^{11}$ Pada poin ini kritik Radbruch terhadap ajaran positivisme yuridis yang membela validitas hukum positif berdasarkan kekuasaan yang mendasarinya sangat tepat. Dikaitkan dengan konteks historisnya, Radbruch menyangkal bahwa UU yang dibuat oleh Nazi-Jerman valid sebagai hukum. UU Nazi-Jerman hanya valid dari perspektif ajaran positivisme yuridis karena basis validitasnya adalah kekuasaan. Sementara dari titik berdiri nilai atau moralitas, UU tersebut tidak mungkin valid sebagai hukum.

Pandangan demikian diperkuat oleh pendapat Tatsuo Inoue yang dinamakan 'the concept of law as a project for justice'. Pendapat ini menjustifikasi tuntutan mengapa UU harus adil. Inoue membedakan antara pernyataan yang bersifat normatif dengan yang bersifat imperatif. Hukum adalah pernyataan yang bersifat normatif karena keadilan inheren didalamnya. Berbeda dengan pernyataan yang bersifat imperatif seperti ancaman senjata api seorang penjahat, yang semata-mata dasarnya adalah kekuasaan, tanpa perlu mengklaim dirinya berlaku adil, supaya orang yang di bawah todongan itu tergerak. ${ }^{12}$

Dengan demikian maka isu selanjutnya adalah prinsip-prinsip moral supaya sesuatu dapat menyandang nama hukum secara sah. Dalam rumusan positif yang masih abstrak Edgar Bodenheimer menyatakan: "From the point of view of justice, we are deeply interested in the fairness and reasonableness of these rules, principles, and standards, their effects upon human beings, and their worth as measured in terms of their contribution to human happines and productive human effort."13 Jika pernyataan tersebut dinyatakan kembali dalam kaitan dengan isu prinsip-prinsip moral internal dalam hukum maka kesimpulannya adalah hukum harus mencerminkan fairness, reasonableness, memberikan kontribusi positif terhadap human happiness dan productive human effort. Inilah hukum dalam pengertian sebagai ius seperti dideskripsikan Pound.

10 Robert Alexy, The Argument from Injustice: A Reply to Legal Positivism (Oxford University Press 2004) 6 .

11 Statutory Non-Law and Suprastatutory Law, 13 dalam Heather Leawoods, 'Gustav Radbruch: An Extraordinary Legal Philosopher' (2000) 2 Washington University Journal of Law and Policy 489, 497498.

12 Tatsuo Inoue, The Rule of Law as the Law of Legislation dalam Luc J. Wintgens ed., Legislation in Context: Essays in Legisprudence (Ashgate 2007) 65.

13 Edgar Bodenheimer, Jurisprudence: The Philosophy and Method of the Law (Harvard University Press 1970) 177. 


\section{UU sebagai Hukum Harus Bermoral}

Pembahasan sub-judul ini difokuskan untuk mengargumentasi dua isu. Pertama, apakah UU adalah hukum. Kedua, implikasi UU sebagai hukum, yaitu UU harus bermoral. Pendekatan ontologis atas konsep hukum yang demikian disebut pendekatan normatif, yang menekankan pada aspek ideal sebagai unsur konstitutif dari hukum, termasuk UU. ${ }^{14}$ Seperti telah dijelaskan sebelumnya, secara prinsip UU tidak musti adalah hukum. Untuk sampai pada tahap bahwa UU adalah hukum maka sifat hukum yang hakiki, konsep ontologisnya yang benar, harus terefleksi atau terpancar dalam UU. ${ }^{15}$

UU (atau legislasi) secara hakiki merefleksikan metode untuk memberi bentuk pada hukum yang dilakukan oleh negara. Menurut John Salmond, "Legislation is that source of law which consists in the declaration of legal rules by a competent authority." 16 UU memiliki makna sangat penting karena menurut Roger A. Shiner, "Legislation appears intuitively as the paradigm source of law."17 Dalam pengertian demikian, sebagai implikasinya, Shiner mengklaim, "For there to be law, we need a way of identifying which norms are legal norms; we need an agency to introduce new laws, or amend the ones that exist."18 Peran pembentuk UU sangat sentral dalam membedakan suatu kaidah/norma apakah hukum atau tidak (misalnya kaidah moral). ${ }^{19}$

Sesuai dengan isu pertama subjudul ini maka yang harus lebih dulu dipecahkan adalah pertanyaan apakah UU adalah hukum. Jawaban relatif aman adalah UU merupakan salah satu sumber hukum, yaitu hukum yang diberikan bentuk spesifik oleh negara melalui pembentuk UU-nya. Oleh karena itu, kesimpulannya, pada analisis akhir, UU dapat menjadi hukum atau sebaliknya. Hal itu bergantung pada substansi yang diberikan bentuk oleh negara. 20

Sejalan dengan pengertian tersebut, ajaran filsafat hukum klasik menyatakan sebagai prinsip: "lex iniusta non est lex" (atau secara harafiah "UU yang tidak adil bukan UU"). Ajaran ini dikemukakan oleh St. Augustine, dan menurut Suri Ratnapala mengandung pengertian: "at some point on the moral scale an enactment may be seen as so immoral or unjust that it loses its authority as law."21 Pernyataan tersebut pada hakikatnya merupakan jawaban atas isu hukum pertama yang ingin

14 Patrick J. Kelley, 'Theories of Legislation and Statutory Interpretation: Natural Law and the Intention of the Legislature' (2009) 1 Washington University Jurisprudence Review 97, 98. Secara umum bandingkan dengan Joseph William Singer, 'Normative Method for Lawyer' (2009) 56 UCLA Law Review 899, 899-982.

15 Titon Slamet Kurnia, 'Hukum dan Keadilan: Isu Bagian Hulu dan Hilir' (2016) 10 Refleksi Hukum 17, 19-25.

16 Roger A. Shiner, Op.Cit., 10.

17 Ibid., 7.

18 Ibid.

19 Martin Krygier, 'Law as Tradition' (1986) 5 Law and Philosophy 237, 245-250; Martin Krygier, 'The Traditionality of Statutes' (1988) 1 Ratio Juris 20, 23-24.

20 Krishna Djaya Darumurti, 'Perspektif Filosofis Kekuasaan Diskresi Pemerintah' (2014) 8 Refleksi Hukum 41, 52.

21 Suri Ratnapala, Jurisprudence (Cambridge University Press 2009). Ajaran tersebut kemudian dikembangkan/dipertahankan secara spesifik oleh Thomas Aquinas dan Gustav Radbruch. 
dijawab sub-judul ini. Itu artinya, secara kontekstual, jawaban atas pertanyaan apakah UU adalah hukum bersifat relatif karena, seperti diyakini oleh MK Jerman, pembentuk UU sangat mungkin membentuk UU yang tidak sesuai hukum (menghasilkan lex iniusta atau unjust laws).

Lebih lanjut, sebagai implikasinya, jika hendak dihasilkan UU yang legitimate sebagai hukum, hal itu merupakan isu kedua pembahasan ini. Dalam kaitan dengan isu kedua penulis hendak mempertahankan argumen bahwa UU sebagai hukum, harus bermoral, tidak boleh 'tidak adil' (iniusta atau unjust). Jika dikaitkan kembali dengan pendapat Bodenheimer di atas maka secara substantif UU harus merefleksikan: "the fairness and reasonableness of these rules, principles, and standards, their effects upon human beings, and their worth as measured in terms of their contribution to human happines and productive human effort."

Dalam kaitan menjawab tuntutan untuk pembentukan UU yang legitimate sebagai hukum, Lon L. Fuller merumuskan pendekatan prosedural dalam pembentukan UU sebagai kriteria moralitasnya yang disebut the morality that makes law possible. Kriteria tersebut dirumuskan Fuller dalam proposisi negatif untuk menggambarkan suatu kondisi yang disebut dengan eight ways to fail to make law, yaitu:

"(a) failure to establish rules at all, leading to absolute uncertainty; (b) failure to make rules public to those required to observe them; (c) improper use of retroactive lawmaking; (d) failure to make comprehensible rules; (e) making rules which contradict each other; (f) making rules which impose equirements with which compliance is impossible; (g) changing rule so frequently that the required conducts become wholly unclear; (h) discontinuity between the stated content of rules and their administration in practice." 22

Secara hipotetis, jika kedelapan kriteria negatif tersebut tidak terjadi maka dapat dipresumsikan bahwa UU yang dihasilkan memenuhi kriteria moral minimal untuk dianggap legitimate sebagai hukum. Kesimpulan demikian belum menjawab pertanyaan apakah secara substantif UU yang dihasilkan sudah bermoral. Kesimpulan yang dihasilkan baru sebatas UU tersebut bermoral secara prosedural (dengan mengikuti prosedur moralitas dalam pembentukan UU), dalam hal ini the morality that makes law possible.

Pandangan substantif untuk konsep UU yang bermoral dikemukakan oleh Thomas Aquinas. Menurut Aquinas, "law is nothing but a rational regulation for the good of the community, made by the person(s) having powers of government and promulgated." Konsepsi hukum dari Aquinas ini adalah kombinasi pendekatan positivisme dan hukum kodrat (natural law). Meskipun dirumuskan sangat abstrak dan sumir, pandangan Aquinas tersebut mengandung kriteria substantif tentang UU yang baik, yaitu: (1) rational regulation; dan (2) for the good of the community. Menjelaskan tentang aspek rasionalitas UU, McCoubrey dan White merujuk pada konsep akal budi atau reason; dan akal budi tertinggi adalah akal budi

22 Hilaire McCoubrey \& Nigel D. White, Textbook on Jurisprudence (Blackstone Press Ltd. 1996) 89-90. 
Tuhan (lex aeterna).23 Oleh karena itu, meskipun dirumuskan sangat sumir, kriteria ini sangat operasional sebagai standar bagi UU bahwa UU harus sesuai dengan akal budi. Jika kebalikannya maka disebut lex tyrannica atau tyrannical law, di mana respons terhadapnya dinyatakan dengan prinsip: "lex tyrannica cum non sit secundum rationem non est simpliciter lex sed magis est quaedam perversitas legis" (A tyrannical law made contrary to reason is not straighforwardly a law but rather a perversion of law). ${ }^{24}$

Secara yuridis, di Indonesia, dalam upaya untuk mencapai tujuan supaya UU legitimate sebagai hukum, dalam UU No. 12 Tahun 2011 tentang Pembentukan Peraturan Perundang-Undangan dirumuskan sejumlah pembatasan baik prosedur maupun substansi dalam menghasilkan UU. Pembatasan mengenai prosedur disebut asas-asas pembentukan peraturan perundangundangan yang baik. ${ }^{25}$ Pembatasan mengenai substansi disebut asas-asas materi muatan peraturan perundangundangan. ${ }^{26}$ Secara teoretis, dengan dua pembatasan tersebut, diharapkan bahwa UU No. 12 Tahun 2011 mampu menjadi prakondisi untuk menghasilkan UU yang bermoral, bukan UU yang dasarnya semata-mata adalah kekuasaan.

\section{Perspektif Filosofis UU MD3}

Sub-judul ini merupakan inti dari artikel secara keseluruhan. Dalam kaitan itu hanya Pasal 84 UU MD3 yang mengatur tentang mekanisme penentuan Pimpinan DPR, khususnya pada ayat (1) dan (2), yang akan dimasalahkan. Implikasi ketentuan tersebut adalah hilangnya kesempatan partai politik pemenang Pemilu untuk memperoleh posisi Ketua DPR secara otomatis. Poin utama penulis, UU MD3 baru lebih tepat disebut sebagai politik, ketimbang hukum, karena mengandung cacat moral baik substantif maupun prosedur. MK yang menguji Pasal 84 UU MD3 gagal dalam mengambil putusan yang mencerminkan moralitas inheren hukum yang harus dipenuhi oleh UU supaya layak disebut hukum dengan membiarkan pragmatisme dari pembentuk UU berlaku sebagai kaidah. Posisi MK di sini positivis (formalis), ketimbang normativis.

Fokus analisis filosofis terhadap Pasal 84 UU MD3 baru adalah bad legislative intent dari pembentuk UU sehingga berakibat produknya tidak bermoral. UU MD3 adalah produk keputusan pada menit-menit akhir oleh pembentuk UU yang akan segera berakhir masa jabatannya, padahal substansinya sendiri sangat strategis karena berbeda secara fundamental dari UU MD3 sebelumnya yaitu UU No. 27 Tahun 2009. Ketika UU MD3 tersebut diuji oleh MK nampak adanya, dalam bahasa Pemohon, konspirasi politik oleh mayoritas pembentuk UU untuk merampas hak partai politik pemenang pemilu guna mendapatkan posisi Ketua

\footnotetext{
$23 \quad$ Ibid., 73.

Ibid., 74.

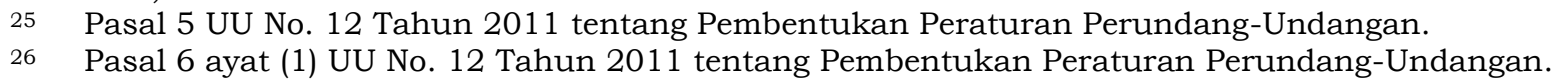


DPR secara otomatis. 27 Unsur konspirasi tersebut dibuktikan dengan perubahan kebijakan legislatif secara drastis mengenai mekanisme pengisian jabatan Pimpinan DPR di mana hal itu dilakukan di luar perencanaan awal, tetapi patut diduga sangat dipengaruhi oleh konfigurasi politik hasil Pemilu Legislatif dan Pemilu Presiden 2014.28

Secara moral, kasus UU MD3 baru ini sesungguhnya sangat sederhana. Cara mudah untuk memahami Pasal 84 UU MD3 baru ini adalah menyandingkannya dengan Pasal 82 ayat (1) s/d (3) UU MD3 lama. UU MD3 lama menentukan bahwa Pimpinan DPR terdiri atas 1 (satu) orang ketua dan 4 (empat) orang wakil ketua yang berasal dari partai politik berdasarkan urutan perolehan kursi terbanyak di DPR. Ketua DPR ialah anggota DPR yang berasal dari partai politik yang memperoleh kursi terbanyak pertama di DPR, dan Wakil Ketua DPR ialah anggota DPR yang berasal dari partai politik yang memperoleh kursi terbanyak kedua, ketiga, keempat dan kelima. UU MD3 baru mengubah ketentuan tersebut, terutama yang sangat substansial pada Pasal 84 ayat (1) dan (2)-nya. Pada ayat (1) ditentukan bahwa Pimpinan DPR terdiri atas 1 (satu) orang ketua dan 4 (empat) orang wakil ketua yang dipilih dari dan oleh anggota DPR. Pada ayat (2) ditentukan bahwa Pimpinan DPR tersebut dipilih dari dan oleh anggota DPR dalam satu paket yang bersifat tetap.
DPR menjustifikasi keputusan tersebut dengan dua argumen substantif yaitu: menegakkan demokrasi di parlemen dengan mengakui hak anggota DPR untuk memilih dan dipilih di dalam lembaga perwakilan ${ }^{29}$ dan hak pemohon tidak dirugikan karena tetap memiliki kesempatan untuk dipilih menjadi Pimpinan DPR. ${ }^{30}$ Presiden memberikan argumen senada. ${ }^{31}$ Argumen tersebut hanya formalitas belaka karena baik dari sisi demokrasi maupun terbukanya secara sama kesempatan untuk dipilih menjadi Pimpinan DPR adalah hanya berlaku bagi mereka yang mampu membentuk kekuatan mayoritas di parlemen sebelumnya. Inilah masalahnya, pembentuk UU yang menghasilkan UU MD3 adalah kekuatan mayoritas di DPR baru (2014-2019). Itu artinya posisi Pimpinan DPR sudah dikunci lebih dulu ketika UU MD3 diputuskan. Dengan pengertian lain, Pimpinan DPR sesungguhnya sudah dipastikan oleh mayoritas yang memutuskan UU MD3 bersamaan dengan adanya Pasal 84 yang kontroversial tersebut.

Situasi tersebut tidak ditanggapi oleh MK yang bersikap positivis (bebas nilai). Tentang momentum yang tidak tepat MK berpendapat: "mengenai pembentukan UU a quo yang dilakukan setelah diketahui hasil pemilihan umum tidaklah bertentangan dengan UUD 1945 .... hal itu sangat bergantung pada terpenuhinya prosedur pembentuk UU

27 Putusan Mahkamah Konstitusi Republik Indonesia Nomor 73/PUU-XII/2014, Mahkamah Konstitusi, 29 September 2014, 15-16.

Ibid., 27-39.

Ibid., 69-70.

Ibid., 70.

Ibid., 77. 
menurut UUD 1945."32 Padahal dari momentum tersebut dapat diketahui bad legislative intent pembentuk UU.

Posisi MK yang bebas nilai semakin transparan ketika menanggapi tuntutan bahwa konfigurasi Pimpinan DPR harus mencerminkan konfigurasi pemenang Pemilu untuk menghormati kedaulatan rakyat yang memilih dengan menyatakan alasan bahwa pemilihan umum adalah untuk memilih anggota DPR, DPD, Presiden dan Wakil Presiden, serta DPRD, bukan untuk memilih Pimpinan DPR. ${ }^{33}$ Kesalahan MK paling fatal adalah menjadikan realitas politik di Indonesia yang jauh dari ideal sebagai kaidah untuk memperkuat konstitusionalitas Pasal 84 UU MD3, MK menyatakan:

"Dalam praktik politik di Indonesia yang menganut sistem presidensial dengan sistem multi partai, kesepakatan dan kompromi politik di DPR sangat menentukan ketua dan Pimpinan DPR, karena tidak ada partai politik yang benar-benar memperoleh mayoritas mutlak kursi di DPR, sehingga kompromi dan kesepakatan berdasarkan kepentingan adalah sesuatu yang tidak bisa dihindari." 34

Realitas politik tersebut seyogianya diubah dengan instrumen hukum, bukan dijadikan alasan pembenar untuk suatu ketentuan UU yang secara moral masih mengandung tanda tanya besar.

Hakim Konstitusi, Arief Hidayat, memberikan dissenting opinion yang sedikit menyelamatkan marwah MK.
Arief Hidayat mengemukakan pemikiran bahwa meskipun UU MD3 berada di ranah opened legal policy pembentuk UU untuk menentukan mekanisme pemilihan Pimpinan DPR, namun politik hukum yang dipilih perlu diuji konstitusionalitasnya karena tidaklah berarti politik hukum demikian bersesuaian dengan konstitusi. ${ }^{35}$ Arief Hidayat menyoroti pragmatisme dan conflict of interest dalam keputusan menghasilkan UU MD3 ketika hal itu dilakukan setelah hasil Pemilu Legislatif diketahui:

"Ketiadaan pengaturan yang rigid dan eksplisit dalam konstitusi melahirkan suatu konsepsi pilihan kebijakan hukum yang bersifat terbuka (opened legal policy) yang memberikan kewenangan kepada pembuat undangundang untuk menjabarkannya lebih lanjut... Akan tetapi haruslah tetap diingat akan adanya batasan untuk melakukan perubahan itu, yaitu tidak hanya semata-mata didasarkan pada kepentingan yang bersifat pragmatis sesaat sesuai dengan kepentingan sekelompok atau segolongan orang, tetapi haruslah ditujukan untuk tujuan yang ideal bagi seluruh orang." 36

Pendapat di atas sangat tepat dalam menilai kasus ini secara keseluruhan. Pragmatisme pembentuk UU dalam menghasilkan UU MD3 adalah starting point untuk memasalahkan moralitasnya dan hal itu sangat berkaitan dengan legitimasi dari UU MD3 secara keseluruhan. Dalam kasus ini pembentuk UU telah gagal dalam mengambil keputusan secara imparsial, tetapi mengalami
Ibid., 212.

Ibid., 216.

Ibid.

Ibid., 229-230.

Ibid., 224. 
conflict of interest sehingga gagal dalam mewujudkan, meminjam pendapat Thomas Aquinas, a rational regulation for the good of the community. Pembentuk UU yang menghasilkan UU MD3 bertindak sebagai hakim bagi kasusnya sendiri, setelah tahu bahwa hasil Pemilu Legislatif tidak menguntungkan kepentingan politiknya di masa yang akan datang. Dengan jeli Arief Hidayat mengingatkan:

"Untuk menghindari conflict of interest dan tetap menjaga asas nemo judex indoneus in propria (tidak seorangpun dapat menjadi hakim dalam perkaranya sendiri) dalam memutuskan norma pada UU a quo ini penting untuk ditelusuri dan dipastikan apakah badan/lembaga yang memutus terkait aturan/ketentuan tentang dirinya sendiri tersebut telah melakukannya sesuai dengan prinsip-prinsip hukum, menjaga imparsialitas, mengesampingkan kepentingan dirinya dan menempatkan kepentingan publik serta amanat konstitusi di atas kepentingan diri atau kelompoknya. Untuk menghindari hal tersebut maka menurut saya semestinya perubahan UU a quo haruslah dilakukan jauh sebelum diketahuinya hasil pemilihan umum lembaga perwakilan rakyat tahun 2014."37

Seyogianya, untuk lebih mempertegas posisinya, Arief Hidayat perlu menyatakan bahwa larangan konflik kepentingan adalah kaidah universal dan merupakan kaidah konstitusi itu sendiri sehingga sangat relevan untuk menilai konstitusionalitas UU MD3 dan kemudian menyatakan bahwa UU MD3 tersebut, karena melayani kepentingan sendiri dari mayoritas pembentuk UU, merupakan a perversion of law atau perversitas legis. Pembentuk UU perlu diingatkan bahwa dia memiliki kewajiban untuk menghasilkan UU yang bermoral supaya UU-nya legitimate sebagai hukum.

\section{PENUTUP}

Seperti ditampilkan dalam pembahasan ini, wajah hukum menjadi sangat buram ketika secara sewenang-wenang pembentuk UU menggantikan UU MD3 lama dengan UU MD3 baru. Dari analisis filosofis yang dilakukan nampak bahwa UU MD3 baru mengandung cacat inheren berupa tidak tercerminnya moralitas internal hukum di dalamnya. UU MD3 baru mengandung bad legislative intent berupa pragmatisme dan konflik kepentingan dari pembentuk UU sehingga kualitas moral UU-nya layak dipertanyakan.

Dengan analisis filosofis atas UU MD3 yang didasari oleh konsep ontologis hukum yang sebenarnya, bukan seperti ajaran positivisme yuridis yang mengutamakan segi formal dari hukum serta bersifat bebas-nilai atas pertanyaan menyangkut hal-hal substantifnya, dapat diidentifikasi isu moralitas serius dari UU MD3. Persepsi yang dapat dikonstruksi dari kasus UU MD3 adalah: UU tersebut tidak lebih dari kekuasaan. Barangsiapa memegang kekuasaan mayoritas sebagai pembentuk UU maka UU adalah miliknya. Tetapi sesungguhnya, secara moral, UU MD3 yang dipermasalahkan ini bukanlah hukum; ini hanyalah UU yang dihasilkan oleh mayoritas 
pemegang kekuasaan legislatif di negeri ini. Isu legitimasi moral akan tetap menghantuinya dan menjadi sejarah kelam politik di Indonesia yang hendak melegitimasi dirinya melalui hukum, dengan UU, sehingga pragmatisme adalah moralitas UU tersebut.

\section{DAFTAR BACAAN}

\section{Buku}

Alexy, R., The Argument from Injustice: A Reply to Legal Positivism (Oxford University Press 2004).

Bodenheimer, E., Jurisprudence: The Philosophy and Method of The Law (Harvard University Press 1970).

Kelsen, H., The Pure Theory of Law (University of California Press 1967).

Kurnia, Titon S., Interpretasi Hak-Hak Asasi Manusia oleh Mahkamah Konstitusi Republik Indonesia: The Jimly Court 2003-2008 (Mandar Maju 2015).

McCoubrey, H., \& White, Nigel D., Textbook on Jurisprudence (Blackstone Press Ltd. 1996).

Pound, R., Law Finding Through Experience and Reason (University of Georgia Press 1960).

Ratnapala, S., Jurisprudence (Cambridge University Press 2009).

Shiner, Roger A., A Treatise of Legal Philosophy and General Jurisprudence Vol. 3: Legal Institutions and the Sources of Law (Springer 2005).

Wacks, R., Understanding Jurisprudence: An Introduction to Legal Theory (Oxford University Press 2012).

\section{Artikel Jurnal}

Bedner, A., 'Indonesian Legal Scholarship and Jurisprudence as an Obstacle for Transplanting Legal Institutions' (2013) 5 Hague Journal on the Rule of Law.

Darumurti, Krishna D., 'Perspektif Filosofis Kekuasaan Diskresi Pemerintah' (2014) 8 Refleksi Hukum.

Fuller, Lon L., 'Positivism and Fidelity to Law - A Reply to Professor Hart' (1958) 71 Harvard Law Review.

Kelley, Patrick J., Theories of Legislation and Statutory Interpretation: Natural Law and the Intention of the Legislature' (2009) 1 Washington University Jurisprudence Review.

Krygier, M., 'Law as Tradition' (1986) 5 Law and Philosophy.

Kurnia, Titon S., 'Hukum dan Keadilan: Isu Bagian Hulu dan Hilir' (2016) 10 Refleksi Hukum.

Leawoods, H., 'Gustav Radbruch: An Extraordinary Legal Philosopher' (2000) 2 Washington University Journal of Law and Policy.

Singer, Joseph W., 'Normative Method for Lawyer' (2009) 56 UCLA Law Review. , The Traditionality of Statutes' (1988) 1 Ratio Juris 20.

\section{Artikel dalam Antologi dengan Editor}

Inoue, T., 'The Rule of Law as the Law of Legislation' dalam Luc J. Wintgens ed., Legislation in Context: Essays in Legisprudence (Ashgate 2007). 


\section{Putusan Pengadilan}

Putusan Mahkamah Konstitusi Republik Indonesia Nomor 73/PUUXII/2014, Mahkamah Konstitusi, 29 September 2014.

\section{Peraturan Perundang-Undangan}

Undang-Undang Nomor 27 Tahun 2009 tentang Majelis Permusyawaratan Rakyat, Dewan Perwakilan Rakyat, Dewan Perwakilan Daerah dan Dewan Perwakilan Rakyat.

Undang-Undang Nomor 12 Tahun 2011 tentang Pembentukan Peraturan Perundang-Undangan.

Undang-Undang Nomor 17 Tahun 2014 tentang Majelis Permusyawaratan Rakyat, Dewan Perwakilan Rakyat, Dewan Perwakilan Daerah dan Dewan Perwakilan Rakyat. 